Engineering Happiness 



\section{Engineering Happiness}

A New Approach for Building

a Foyful Life

Manel Baucells and Rakesh Sarin

甲ㅜ

UNIVERSITY OF CALIFORNIA PRESS

Berkeley Los Angeles London 
University of California Press, one of the most distinguished university presses in the United States, enriches lives around the world by advancing scholarship in the humanities, social sciences, and natural sciences. Its activities are supported by the UC Press Foundation and by philanthropic contributions from individuals and institutions. For more information, visit www.ucpress.edu.

University of California Press

Berkeley and Los Angeles, California

University of California Press, Ltd.

London, England

(C) 2012 by The Regents of the University of California

Library of Congress Cataloging-in-Publication Data

Baucells, Manel, I966-

Engineering happiness : a new approach for building a joyful life / Manel Baucells and Rakesh Sarin.

p. $\mathrm{cm}$.

Includes bibliographical references and index.

ISBN 978-0-520-26820-3 (cloth : alk. paper)

ISBN 978-0-520-2682I-o (pbk. : alk. paper)

I. Happiness. I. Sarin, Rakesh, 1948- II. Title.

BF 575 . $\mathrm{H} 27 \mathrm{~B} 382 \mathrm{OI} 2$

I52.4'2- dc23

Manufactured in the United States of America
$\begin{array}{llllllllll}20 & \text { I9 } & \text { I8 } & \text { I7 } & \text { I6 } & \text { I5 } & \text { I4 } & \text { I3 } & \text { I2 } & \text { II }\end{array}$
IO $\quad \begin{array}{lllllllll}9 & 8 & 7 & 6 & 5 & 4 & 3 & 2 & \text { I }\end{array}$

The paper used in this publication meets the minimum requirements of ANSI/NISO Z39.48-I992 (R 2002) (Permanence of Paper). 


\section{To my parents-Manel \\ To Anna, Kavita, Ravi, Kyle, and Katelyn-Rakesh}

Our stable sources of happiness 
